"Its ambition is to rule the land. Its opportunity is not far in the future. Its triumph, when it comes, will be complete. The West is to be the dictator of the Republic."

This is what Chief Keokuk was yielding to the might of the advancing civilization. This is what Captain Allen was taking over as he raised the little American flag at the Raccoon forks of the Des Moines. Truly the soul of the west was on fire, and that fire has never been quenched.

Another day has been marked off on the calendar of eternity; many more stars have been added to the blue field of the flag of the free; there will never again be a leisurely million years for this region; the pattern has been set for man's abode in this magnificent dwelling place.

It is the immediate task and high duty of our generation, of all of us who have so richly inherited from the courage and the genius of the pioneers, to see to it that in this "mint of the country," it can always be said that "its soul is on fire."

For a full century, the City of Des Moines, capital of an empire of overflowing abundance, has fulfilled its assigned part in this noble adventure.

\title{
FORT DES MOINES AND DES MOINES ${ }^{8}$
}

\section{By Vernon R. Seeburger}

Des Moines is one hundred years old today. It was founded by the United States Army under the leadership of Capt. James Allen, who, with fifty-two dragoons, landed at the Raccoon forks on the afternoon of May 20, 1843. Because of the rather unusual reasons for locating a fort at this place and at that particular time, pass for the moment a description of the fort, the topography at that place as it existed then, and go back into some of our earlier American history because it dovetails into the actual establishment of the fort here.

Following the War of 1812 a tremendous surge of emigration took place from the Atlantic seaboard over the Allegheny mountains into the so-called northwestern territories, or the Northwest Territory. That area comprised the present states of Ohio, Michigan, Wisconsin, Indiana and Illinois. You will recall from the reading of history that the Indian tribes in that area allied themselves with

\footnotetext{
${ }^{8}$ Address delivered by Vernon R. Seeburger, president of Des Moines Pioneer club, at the Des Moines Centennial program in the Des Moines eity council chamber May 20, 1943 and before several city clubs.
} 
the British during the War of 1812 , and harassed the few settlers who were in that area before the war, so that the region was unsafe for settlement. However, with the termination of that war people poured into the area, because the government speedily took charge of the Indian situation by the establishment of many frontier forts, the removal of many of the Indians to the southwest, and supervision over most of those who remained. Among those who still remained at the year 1832 were the Sac and Fox Indians, of which tribe Mr. Jonas Poweshiek and his two children are representatives here today. Those Indians inhabited in the year 1832 an area what we might now call western Illinois along the Mississippi river and eastern Iowa. There were frequent conflicts between the tribes and the settlers. We white folk like to arrogate to ourselves a sort of piety, but unfortunately some of our handling of the Indian situation does not quite bear out that label. The Indians charged that the whites were committing atrocities against them, with debauching the Indians by the sale of whisky, by the stealing of their live stock and their crops, seizure of their lands, squatting on them by squatters, and shoving the Indians out.

On the part of the whites it was claimed that the Indians were committing atrocities against them, and there the argument stood.

Regardles of its merits, this fact stands out in history, that in the year 1832 Black Hawk, one of the most remarkable Indians who ever lived, and incidentally one of the greatest men, white or red, that this country has ever produced, a muscular specimen of manhood, over six feet tall, and large in all proportions, had as his home the village of Saukenuk, which was situated at the present site of the town of Rock Island, Illinois. For years his tribe had occupied that spot; that was its home. Black Hawk was its chief. They had homes, their wikiups, for they were Algonquin Indians. One the the characteristics of that tribe was the construction of the well-known wikiup as distinguished from the tepee Indians, represented by the Sioux and many other Indians.

On coming home from a trip Black Hawk found some squatters in possession of the homes of his people, the same as you might go home from this building today and find some obstreperous individual in your house, and those people, those squatters, refused, upon Black Hawk's demand, to get out. Becoming enraged, as anyone would, Black Hawk rallied a considerable segment of the Sac and Fox Indians and the Black Hawk war started. In that famous struggle were such well known persons in American history as Gen. Winfield Scott, Abraham Lincoln and Jefferson Davis. Many others might be named who participated in that struggle.

As might be supposed, because of the numerical superiority of the white people, the Indians after several months of fighting, were 
nearly decimated, and the remainder of them retired west of the Mississippi river.

That was in the year 1832 , and immediately the government placed Black Hawk on a reservation with his people, the Sacs, somewhat west of the present town of Davenport. Keokuk, who had remained loyal to the whites, and who had refused to participate, with the Fox Indians, those that he represented in the struggle, were placed on a reservation in southern Iowa, somewhat northwest of the present city of Keokuk.

\section{WARRING INDIAN TRIBES SEPARATED}

North of the Black Hawk reservation there was established the so-called neutral strip, a strip of land forty miles wide that extended from the Mississippi river to the upper waters of the Des Moines river, and in that strip were placed the Winnebago Indians, a sort of buffer group, to separate the Sac and Fox on the south from the Sioux family on the north. The Sioux occupied the area north of the neutral land. The Sac and Fox were bitter enemies of the Sioux. All of those tribes originally came from the eastern part of our country, and some of them from southern Canada, particularly the Sac and Fox Indians, and hostilities between them were of long standing; so the government deemed it wise to separate them by this neutral strip, in the hope of promoting peace and harmony on the frontier.

With the removal of the Indians from Illinois, white civilization poured into Illinois, took up the cheap lands, and then started pushing across the Mississippi. The government under those conditions was again forced to ask the Indians to move and permit the settlement of eastern Iowa by the white civilization, which was incidentally demanding that the Indians be ousted. Several treaties were made during that period from 1832 to 1842 . Finally in 1842, on October 11th, a council was held at a little villiage near the present town of Agency, Iowa, east of Ottumwa, on the Des Moines river, which was participated in by the Sac and Fox Indians and the government. Keokuk represented the Sac or Sauk tribes; Poweshiek, the great grandfather of Jonas Poweshiek of the State Department of History and Archives, who is here today, the Fox Indians. Previous to that and following the Black Hawk war, a series of military posts had been established in Western Illinois, western Wisconsin, and as far north as Fort Snelling in Minnesota, and in eastern Iowa for the protection of the military, and among them was the first Fort Des Moines, which was built upon the west bank of the Mississippi near the present town of Montrose, Iowa, about midway between the present towns of Keokuk and Fort Madison. 
On account of the making of these new treaties with the Indians and pushing them back further and further into the interior of Iowa, it was thought wise to establish a defense post west of Fort Des Moines, so a temporary post known as Fort Sanford was established near Agency on the Des Moines river, just shortly before the treaty of 1842. Fort Sanford was only a temporary post because under the treaty of 1842 it was provided that the Indians should be moved out of eastern Iowa and moved west of a meridian drawn north and south through the Red Rocks in Marion County, Iowa, the Red Rocks being a celebrated quarry which is to be found even today at the site of the town of Red Rock, Iowa, about thirty-five miles southeast of here. East of that line was the limit of white civilization, the furthest that white civilization could go, and west of that line was Indian country.

\section{PROTECTION FOR THE INDIANS}

Now, the thing that led to the establishment of Fort Des Moines at this particular location and at the time that it was established was this very unusual, this unique, provision of the treaty of 1842 . The Sac and Fox Indians who had had so much trouble with the white people, so much trouble from encroachment by squatters and whisky sellers and others who were trying to take away their lands, demanded as part of the agreement to give up their lands in eastern Iowa that the government establish a military post in the new Indian country for the protection of the Indians from the whites. That is somewhat of a reversal from the usual idea that we people have in this country that the posts ${ }^{9}$ were all established to protect the whites from the Indians.

Before 1842 when this treaty was drawn up it became apparent that something would have to be done to handle the Indian situation, so the government as early as 1834 commenced exploratory operations through this territory right through here. It is interesting to know that as early as 1763 there was published in London a map of the Louisiana territory, as it was called, and that the map of the Des Moines river, not under the name Des Moines river, but Moingona river, was represented, and the remarkable thing about it is that the course of the river was pretty well established on that map, that is, it took a southeastern to northwestern course, but the head waters of the river, as is plain from the map, were evidently hazy in the mind of the map maker because he did not locate the head waters correctly, as has been shown since.

The next person we know to have been in this terirtory was Fari-

9Establishment of army posts: Fort Madison, 1808; Fort Crawford, 1816; Fort Edwards, 1816; Fort Armstrong, 1816; Fort Atkinson, 1840 ; Fort Croghan, 1842; Fort Sanford, 1842; Fort Des Moines No. 1, 1834; Fort Des Moines No. 2, 1843 ; Fort Clark, 1850; Fort Des Moines No. 3, 1900. 
bault, who spent two or three years of time some 200 miles from the mouth of the Des Moines river by land, which would place him some place between the present towns of Fort Dodge and Boone trading with the Sioux Indians. He is known in the year 1800 or 1801 to have made a canoe trip with his furs down the Des Moines river past Des Moines to St. Louis where he disposed of his furs. He was a representative of one of the great fur companies of that day.

From then on until 1834 there apparently were no visitors, no white visitors in this area, but in that year one John Daugherty was sent out by the United States Army to explore the Des Moines river as far north as the Raccoon forks. He evidently did a pretty good job because he made a very thorough report on the region, and took it back to St. Louis, and the following year as a result of the findings in that report some very important personages visited this area. Among them were the following, Capt. Nathan Boone, son of the famous frontiersman Daniel Boone, came here. $\mathrm{He}$ marched up the Des Moines river to the Raccoon forks, crossed the Des Moines at the ford which used to be out here in the approximate vicinity of the Locust Street bridge, and encamped on the east bank of the river, probably right where this Municipal building stands. That was in the year 1835 . He then retired towards eastern Iowa, made his report on the region, which is an elaborate report.

The same year Albert M. Lea, a lieutenant in the United States Army, was sent out by the army to explore not only the region up to the Raccoon forks, but the head waters of the Des Moines river, and his journal furinshes one of the most succinct accounts of this interior Iowa country that was ever been written. He went up the river as far as Minnesota, came back and struck the head waters of the Raccoon river, followed the Raccoon down to what is approximately Dallas County. And for the interest of you big game hunters, one of his dragoons shot a bear out in Dallas County near the present site of Minburn. He also mentions the buffalo they saw on that trip, also elk, deer and many other animals.

Another visitor that year was Col. George Croghan, who was sent out to explore the Des Moines river country, and he made a very favorable report upon the Raccoon forks as being a place highly suitable for the establishment of a military post. However, an adverse note was thrown into the picture that same year by Col. Stephen Watts Kearny, who explored this same region but reported adversely upon it, thinking it was not suitable for the establishment of a military post. Col. Kearny became one of our famous soldiers in the Mexican war and participated along with Gen. John C. Fremont in the conquest of California. 
Nothing more seems to have been done about this region until the year 1841, at which time the government sent John C. Fremont to this area. He was not only a military man, a professional engineer of the army, but he was also a scientist, a man who knew the botanical life of the region, the animal life of the region, and he described it not merely by the common names that you and I know the trees and flowers, but he added the Latin names as well; he was that well versed in the study of botany. He made an elaborate report covering not only the flora and fauna of the region, but the other resources as well.

\section{ACTUAL LOCATION OF THE FORT}

That brings us down to the year 1842. That year immediately following the signing of the treaty at Agency on October 11th, Capt. James Allen was dispatched that fall up the Des Moines river with instructions to recommend a site for the military fort to comply with the provisions of the treaty. He came up the river, and evidently decided in his own mind that the Raceoon forks should be the site, because the following February he was directed by the war department as soon as weather permitted to again go up the river and locate the fort.

On April 29, 1843, Capt. James Allen with a small detail of men came up the Des Moines river by boat, disembarked at the Raccoon forks and selected this as the site for the fort. He left his men in charge of the supplies that were brought up, went back down the river to Fort Sanford from which he had started, and which was his headquarters up to that time, and reported to the war department under date of May 10, 1843, that he had located the fort, and on the 18th day of May was proceding back up the river to start its construction. On the boat Agatha he took his leave from Fort Sanford, and with fifty-two dragoons and several Indian chiefs of the Sac and Fox Indians and their squaws, came up the river and two days later on the afternoon of May 20th landed at about the vicinity of the Court Avenue bridge here in Des Moines, disembarked, raised the flag, and started construction of the fort. The next day he was joined by a company of infantry that had marched overland from Fort Crawford at Prairie du Chien on the Mississippi river, and those two groups, the infantry and the dragoons, who were the mounted infantry of that day-today we call them cavalry-started the construction of the fort. The first thing built was a dock for the landing of supplies from the boats. The next thing was a storehouse, the next building a hospital. From then on the quarters for the men and the officers were built, and until the fort was completed in the fall of 1843 there were ninety-nine soldiers and officers stationed at this fort. 
In order to clear up a popular misapprehension as to the exact location of the fort, I am going to tell you as best I can just where these buildings stood and the land they covered, because the topography of that day in that vicinity was considerably different than it is today. You who are connected with the city and particularly the city engineering department know that several years ago the channel of the Raccoon river was moved from its original location where the north bank of the river was about 200 feet or thereabouts south of Elm Street, moved some seven or eight hundred feet souch and the old bed of the river filled up, so that part of the land that today is north of the Raccoon river in the days of the fort was actually south of the Raccoon river and not a part of the military reservation at all. Where the D. A. R. monument marking the site now stands was approximately the bed of the old Raccoon river in the days of the fort. Where it stood before it was moved was just slightly north of the confluence of the two rivers, a matter of only a few feet north of the original north bank of the Raccoon river.

The fort occupied an area that was afterwards deeded to Polk County by the United States government, and it was surveyed by A. D. Jones, and was named the Town of Fort Des Moines, and is so named on the county records today. That plat occupies, as I say, the old fort reservation, and it extended from the present Elm Street on the south to the present Locust Street on the north, from the Des Moines river on the east to West Eighth Street on the west.

In the days of the fort, the buildings were grouped about as follows: Along what would be a parallel or reasonably parallel line to the Des Moines river, and extending from the present Elm Street to the site of the present city library and slightly west of First Street as we know it today, in the days of the original plat known as Water Street, was a line of buildings that housed the officers of the post. It was familiarly known to the people then as "Officers Row." At right angles to those buildings and more or less paralleling the Raccoon river running up what would be the north side of Elm Street to approximately Eighth Street were the quarters of the men, the soldiers. In the angle formed by this right angle figure were many small buildings, store houses, stables, corrals, and the flag staff of the military reservation, slightly southeast of what would now be the intersection of Second and Market Streets.

The soldiers put in gardens as soon as they got here because the season, May 20th, was advanced. They immediately enlisted the efforts of civilians in the procuring of supplies, and as a result a considerable number of people were attracted to this vicinity because of the establishment of the fort. So this community goes back to the year 1843. Among those people were several contract 
farmers who were employed under contract by the United States government to furnish food for the men and feed for the animals. Among other people here were blacksmiths, quarrymen to quarry the stone out on Four Mile Creek that was used to make lime and for foundations of the fort buildings. There were also men employed in working the coal bank at Thompson's Bend where the fuel was obtained for heating the fort buildings in the winter. There were also employed saw mill operators who operated the earliest mill in the present Warren County, Iowa. Then a little later grist mill operators were employed to grind the grain for the use of the people here. The steamboat services also had representatives here because in those days, contrary to popular notions today, the Des Moines river was a considerable highway of commerce and was used throughout the year except in winter and during the low water months of summer for the bringing of supplies to the fort and to this upper Des Moines river country.

\section{INDIANS RELUCTANT TO LEAVE}

The soldiers were pretty busy. The Sac and Fox Indians, as might be imagined, did not want to leave Iowa; they did not want to go to Kansas, and anybody who has been in Iowa in this fruitful valley, particularly that known as the Des Moines river valley, and who has also been in southern Kansas at least years ago before they started raising trees down there, can understand why no group of Indians would want to leave Iowa and go to Kansas, and that is precisely the attitude that was found to exist in the minds of the Indians. So they were inclined to wander away from the fort. The government tried to hold when as close in as possible so as to keep track of them for the three-year period which would expire in October, 1845. In the summer they moved out to the open ground in the area that is now our packing house district, and in the winter they moved back along the Des Moines river for protection from the weather. Other Indians were camped by the Des Moines river in the vicinity of Beaver Creek, some over on the Skunk river; in fact, they were located all around here, on the outskirts of the military reservation.

The whites took a census of the Indians that were to be moved so as to keep track of them. Most of the Indians before the expiration of the treaty had already gone to Kansas, but there were about 200 that remained in October of 1845 . That fall their plight was so bad from the standpoint of food, supplies and transportation that they could not be moved, so Captain Allen asked the permission of the War Department not to remove the Indians until the spring of 1846, and his request was granted.

On March 10, 1846, the Indians, having been rounded up by the 


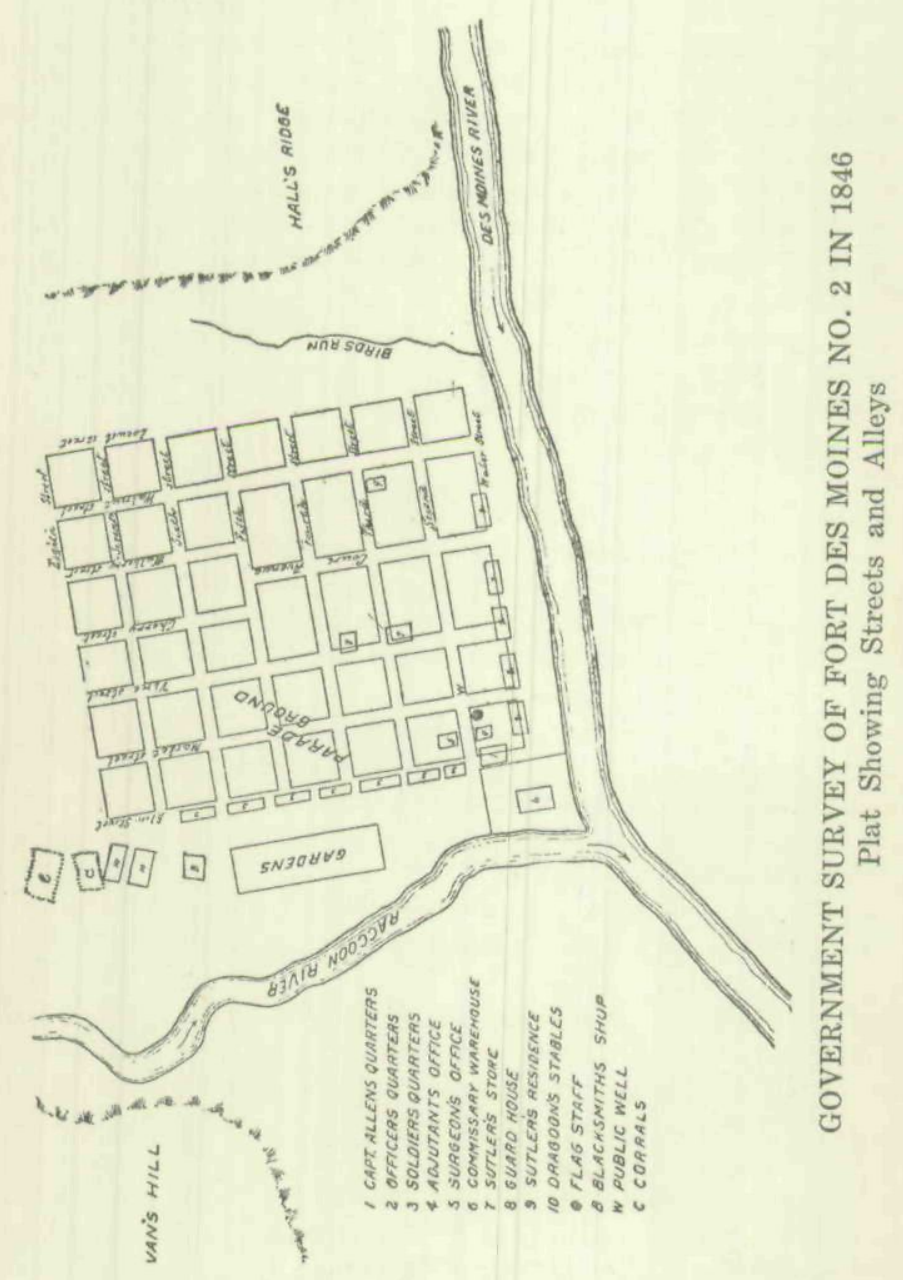


soldiers, and supplies having been obtained from the quartermaster's department for the trip to Kansas, the flag was lowered at the fort, the troops closed the doors of the establishment, and the whole caravan moved across the Raccoon river slightly west of the fork with the Des Moines river, and took up their way to Kansas.

It is recorded in history that the last view that these Indians had of this valley was from the top of what was in those days known as Van's Hill, which is that rather high prominence that one sees today at the south end of the Seventh Street viaduct. You will recall, if you remember the topography there, that the hill is quite high, and if you have been on top, that you can look over all of the Des Moines business district, the confleunce of the two rivers, and further east.

The troops marched the Indians to southern Kansas, but as one might imagine, before the lapse of ten years, large numbers of them had already come back to Iowa. The state taking pity on their plight-because they were wards of the government and could not own land, could not acquire land like you and I can today, and the government refusing to pay them their allotments because they would not live on their reservation - the state of Iowa, taking pity on them, authorized them to purchase ground near the present town of Tama, and they bought eighty acres, which was the start of the Tama Indian Reservation. That was added to as the years went on, the state taking title to more land until it aggregated 3600 acres, and a few years ago it was transferred to the Secretary of the Interior, who now manages that land for the Sac and Fox Indians. But of course, several years ago the Indians were vested with full citizenship rights in this country and now they can be land owners and are electors, too.

\section{FOUNDATIONS FOR A CiTY}

After the fort was abandoned things moved rapidly here. On October 11, 1842, at the sound of a cannon, this great region west of the Red Rock meridian was thrown open to settlement. A rush that rivaled the rush into Oklahoma a few years ago when that state was opened to settlement, had its counterpart here. Men came in and staked out farms, they were allowed 320 acres each, and this whole region was settled, so to speak, and land was taken up in very short order.

On January 17, 1846, the United States government ceded to the county commissioners of Polk County, which had just been organized, the old military reservation. That same spring a county election was held. One of the persons elected was A. D. Jones, a surveyor, who was immediately commissioned by the county commissioners to survey this tract, and he surveyed what is now our 
original town of Fort Des Moines, laid out on the old reservation. It consisted of thirty-seven blocks, exclusive of alleys, streets and public grounds. This area had on it at that time some of the old fort buildings because it is interesting to note in the certificate of the county commissioners that provision was made for the buildings, the public buildings, to be left for a period of one year where they may have encroached or did encroach upon alleys and streets, and so for one year they did not have to be removed. That provision is in the certificate of the commissioners on the plat which is on file today in the office of the county recorder of this county. The plat was filed on July 8, 1846. One week after it was filed an auction sale was held of city lots here in Des Moines, and resulted in prices running up to $\$ 50$ and $\$ 60$ for property that today runs into the hundreds of thousands of dollars in present real estate values.

From then on this community rapidly increased in population. Our population in the year 1846 was 127 persons, and that did not include military personnel. In 1850 , the figures disagree, but the most common figure given as to the population here was 502 persons. In 1860 there was a population of 3965 persons, in 1865 the city council of this city ordered a census taken and at that time there were 5650 persons, and in the year 1870 there were 12,035 persons, which gives you some idea of the growth, which was tremendous in terms of percentage, even in that early day.

This community was to be known as Fort Des Moines for a good many years. That was its official name. In 1851, the first election was held in this city, what is now the city of Des Moines, to determine whether or not Fort Des Moines should incorporate under state law. The vote being favorable, the town incorporated, and about thirty days later the first election was held. In that election eight men were elected as councilmen for the city elected at large, and from that group one of their number was selected to preside. He was known as a president, and he was the well known early-day minister, the Reverend Thompson A. Bird, one of the beloved characters of early Des Moines.

The town as originally incorporated, embraced an area in the neighborhood of 200 acres. Two years later it was reincorporated with an increased area. In 1855 the legislature constituted Fort Des Moines the capital of Iowa, and in 1857 the physical property of the state which was then at Iowa City in the capital building there, was moved to Des Moines. In the same year, 1857, the legislature reincorporated Des Moines as a special charter city under the name of the City of Des Moines. Up to 1857, then, this community, with the exception of a few brief weeks in the first days of the fort, was known as Fort Des Moines, and thereafter as the City of Des Moines. I might say this, for a period of possibly six or 
eight weeks in the year 1843 the name of Fort Raccoon was given to this place. That was upon the recommendation of Captain Allen, but fortunately for us today the name was disapproved by that grizżled old soldier, Gen. Winfield Scott, and the name Fort Des Moines was given to it rather than Fort Raccoon.

\section{Steamboat Travel}

One of the interesting things of that period was the steamboat travel. Today we people who do not use our rivers much are almost amazed to find that the Des Moines not only is today a legally navigable stream, but in the days of the fort, in fact until the railroad came here in 1866 , was in fact a navigable stream, and was used for purposes of commerce. It is reported that as many as five steamboats at a single time were tied up at the wharf here. It is also an historical fact that as late as 1859 steamboat traffic ran up the river as far as Fort Dodge, and in the spring of that year one boat made four trips carrying material and settlers into that locality.

With the coming of the railroad, Des Moines clearly passed out of its pioneer stage and became a city. Business increased rapidly here, it early became an industrial center, the same as today, in large measure, but that is another story and does not pertain to pioneer days.

In conclusion let me say this, Fort Des Moines, established by the United States Army in 1843 as a protecting influence for the Indians, has had continuous community life since May 20th of that year, and up to now, when it has become a real metropolis; and that it was literally carved out of the wilderness just 100 years ago today. I am sure we are all glad that we live in a day when 100 years later we can celebrate the accomplishments of the men who had the vision, the foresight and the courage to enter this region when it was not a region of highways or streets or buildings and the like, but was a region of trees, flowers, Indians and wild animals.

\section{OLD FORT DES MOINES ${ }^{10}$}

\section{By W. M. McLaughlin}

It is said that "great events cast their shadows before them." Therefore, I wish as a preliminary to my talk, to show the con-

\footnotetext{
${ }^{10}$ Address by Wm. M. MeLaughlin, Des Moines attorney, before the Des Moines Real Estate Board and at various meetings during the Centennial Anniversary week of May 20, 1943.
} 
Copyright of Annals of Iowa is the property of State of Iowa, by \& through the State Historical Society of Iowa and its content may not be copied or emailed to multiple sites or posted to a listserv without the copyright holder's express written permission. However, users may print, download, or email articles for individual use. 